\title{
Mandatory IFRS Adoption and Analyst Coverage: Evidence from the UK
}

\author{
Mohammad Issa Almaharmeh ${ }^{1}$, Hamzah Al-Mawali ${ }^{2} \&$ Ghassan Obeidat ${ }^{3}$ \\ ${ }^{1}$ Department of Accounting, Faculty of Management and Finance, The University of Jordan, Aqaba Branch, Jordan \\ ${ }^{2}$ Department of Accounting, School of Business, The University of Jordan, Amman, Jordan \\ ${ }^{3}$ Department of Accounting, Faculty of Management and Finance, The University of Jordan, Aqaba Branch, Jordan \\ Correspondence: Mohammad Issa Almaharmeh, Department of Accounting, Faculty of Management and Finance, \\ The University of Jordan, Aqaba Branch, Jordan. E-mail: m.almaharmeh@ju.edu.jo
}

Received: March 16, 2018 Accepted: September 20, 2018 Online Published: October 29, 2018

doi:10.5539/mas.v12n11p435 URL: https://doi.org/10.5539/mas.v12n11p435

\begin{abstract}
This study investigates whether the mandatory adoption of International Financial Reporting Standards (IFRS) enforce financial analysts to cover the firms with their EPS forecast. After examining a large sample of 10,953 firm year observations from 1,467 distinct UK listed firms for the period between 1990 and 2013, the results suggest that, mandatory IFRS adoption attract more analysts to follow the firms. Where we find the number of financial analyst who cover the IFRS adopters is significantly higher than that for non-adopter firms.
\end{abstract}

Keywords: IFRS, financial analysts, analysts coverage, the UK

\section{Introduction}

This research is motivated by the recent strands in the literature that examine the consequences of the mandatory adoption of IFRS. Where it is expected that IFRS adoption will provide additional disclosure and improve the comparability of financial reporting.This expectation is consistent with a large body of literature that find IFRS adoption leads to a variety of capital market benefits (Daske et al., 2008, Li, 2010, Horton et al., 2013, Houqe et al., 2014, DeFond et al., 2015, Lambert et al., 2012, Kim et al., 2014).Improved transparency and comparability following IFRS adoption is expected to attract more financial analysts (Kim and Shi, 2012). The harmonization of financial disclosure after IFRS adoption is expected to reduce information-processing costs for financial analysts, hence increase the number of financial analysts who follow the firms, and improve the quality of their expectations. prior literature documented this effect Byard et al. (2011), Horton et al. (2013), and Houqe et al. (2014). Where these papers find that the analysts' forecast errors are decreased significantly after the mandatory adoption of IFRS.

However, the improved disclosures via IFRS adoption may reduce analysts' ability to distribute managers' private information to investors, which reduces the information value of analyst services; thereby mitigating the demand for financial analyst services (Healy and Palepu, 2001). Moreover, Kim and Shi (2012) suggest that improved disclosure levels, that associated with mandatory IFRS adoption, reduces the competitive advantage that some analysts would enjoy otherwise, and hence may lower analysts' incentives to cover adopter firms.

We contribute to the previous debate by investigating the effect of mandatory IFRS adoption on the analyst coverage. After collecting and examining 10,953 firm year observations from 1,467 distinct UK listed firms for the period between 1990 and 2013, our results suggest that, the mandatory adoption of IFRS leads significantly to more analysts' coverage. This result is consistent with the findings of Kim and Shi 2012. This paper contributes to the literature that examines the economic consequences of mandatory IFRS adoption. Brüggemann et al. (2012) argue that, most of the literature on the consequences of mandatory IFRS adoption provide transitory evidence with low statistical power because of short history of IFRS adoption, also, they mention that most of these papers provide evidence from cross-country studies which make it difficult to disentangle the effect of IFRS from other synchronous changes that may affect the financial reporting content. Following the recommendations of Brüggemann et al. (2012) this paper used data from one country for a long period after IFRS adoption to draw its results.

In Section 2, we set out the theoretical framework for the study and develop the hypothesis. In Section 3, we describe the sample selection and the measurements of variables used in the study. In Section 4, we discuss the 
research results. In Section 5, we conclude the results of the study.

\section{Prior Research and Hypothesis Development}

In 19/07/2002 the European Union EU parliament issue regulation number 1606/2002, which requires all the firms listed in the EU market to prepare financial statements in accordance with IFRS starting from the 1st of January 2005 (European Parliament, 2008). (Note 1) The main goal of regulation number 1606/2002 is "to contribute to a better functioning of the internal market, publicly traded companies must be required to apply a single set of highquality international accounting rules for the preparation of their consolidated financial statements. Such measure will also ensure high-level transparency and comparability of financial reporting by all publicly traded EU companies as a necessary condition for building an integrated capital market which plays its role effectively, smoothly and efficiently." (European Parliament, 2008).

The new proposed standards are expected to improve transparency and comparability of financial markets, which intern lead to lower information asymmetry and better functioning capital markets (Moscariello, Skerratt, \& Pizzo, 2014).

The adoption of IFRS is considered as an important commitment toward more transparent financial disclosure. Where, the creation of the IFRS was designed primarily to provide more transparent, accurate, comprehensive and timely financial statements information, relative to national accounting standards, including the European countries local standards (Ball, 2006). Corroborating Ball's comments (Ernst\& Young 2006) study suggest that IFRS are considered as more transparent accounting standards as these standards contain a greater number of disclosure requirements than any nationally based standards. According to Ernst and Young (2006) the mandatory adoption of IFRS leads to increases of up to 30 per cent in the length of post-IFRS adoption annual reports for a sample of adopted EU firms.

Several studies examine the economic consequences of IFRS adoption and provide empirical evidence that firm's disclosures under IFRS are of higher quantity and quality than those under local accounting standards in most financial reporting regimes. In particular, the prior IFRS literature find that the adoption of IFRS leads to increases in the value relevance of accounting numbers (Barth et al., 2008; Devalle et al., 2010; Ismail et al., 2013; Tsalavoutas et al., 2012), higher accounting quality (Ballas et al., 2010; Barth et al., 2008; Ismail et al., 2013), improved disclosure quality (Aksu\&Espahbodi, 2012; Daske\&Gebhardt, 2006), more forecast accuracy and lower analysts' forecast dispersion (Horton et al., 2013; Houqe et al., 2014), more earnings information content (Landsman et al., 2012), improve comparability, thus reduce investors information processing cost (Armstrong, Barth, Jagolinzer, \&Riedl, 2010; Daske et al., 2008; M. DeFond et al., 2011), increases in the informativeness of stock prices (Beuselinck et al., 2010; Bissessur\& Hodgson, 2012; Gillberto\& Taboada, 2012; Kim \& Shi, 2012a), reduction in earnings management (Barth et al., 2008; Ismail et al., 2013), increases in timely loss recognition (Barth et al., 2008), higher quality earnings numbers (Houqe et al., 2012), increases in foreign mutual fund ownership (DeFond et al., 2011), increases in the US foreign investments in the countries that adopt IFRS (Shima\& Gordon, 2011), increases in countries foreign direct investment (Gordon et al., 2012; Landsman et al., 2012), reduction in the reporting lag (Landsman et al., 2012), increases in earnings persistent (Doukakis, 2010), lower crash risk, (DeFond et al., 2015), lower firms' cost of equity capital (Daske et al., 2008; Kim, Shi, et al., 2014; S. Li, 2010; Palea, 2009), more transparent and comparable financial disclosure (Brochet et al., 2013), more market liquidity (Daske et al., 2008), and increases equity valuation (Daske et al., 2008).

Since financial analysts considered as one of the most important and sophisticated users of financial statement it is important to examine the effect of mandatory adoption of IFRS on the financial analysts' decision to follow the firm.

Financial analysts are considered as an important provider of information about firms' operations and performance. Prior research suggests that financial analysts are interested in providing common market wide and industry-wide information over expensive firm-specific information. Piotroski and Roulstone (2004)argue that financial analysts are firm's outsiders with limited access to the firm-specific information, unlike management and institutional investors, and for this reason, they suggest that financial analysts try to obtain and process market wide and industry-wide information and map it to stock prices. Chan and Hameed (2006) also, find that financial analysts help in generating and disseminating industry and market level information instead of firm-level information.

In addition, Veldkamp (2006) suggest that financial analysts provide common information because the cost of producing one unit of common information is much smaller than that of firm-specific information, given the high fixed cost of information production.Improved transparency after IFRS adoptionis expected to attract more financial analysts as documented by Kim and Shi (2012). In addition, the harmonization of financial disclosure after IFRS adoption is expected to reduce information-processing costs for financial analysts, hence increase the 
number of financial analysts who follow the firms, also increase the quality of the analysts' activities. This effect is documented by Byard et al. (2011), Horton et al. (2013), and Houqe et al. (2014) who find that the analysts' forecast errors are decreased significantly after the mandatory adoption of IFRS.

On the other hand, the availability of more disclosures via IFRS adoption may preempt analysts' ability to distribute managers' private information to investors. This reduces the information value of analyst services; thereby mitigating the demand for financial analyst services (Healy and Palepu 2001). Moreover, (Kim and Shi, 2012) suggest that improved disclosure levels, that associated with mandatory IFRS adoption, reduces the competitive advantage that some analysts would enjoy otherwise, and hence may lower analysts' incentives to cover adopter firms.Given the fact that there is a lack of evidence on the above issue, this research aims to provide empirical evidence by examining the effect of mandatory adoption of IFRS on the number of financial analysts who follow the firms. Based on the previous discussion our hypothesis is as follow:

H1: The number of financial analysts who follow the firms will be lower following mandatory IFRS adoption.

\section{Sample and Methodology}

In this section, we describe our sample and the methodology used to test the hypothesis developed above. Section 3.1 briefly describes our data sources and the procedures followed in sample selection process, and Section 3.2 provides an overview of our design, along with a detailed description of our variables. We use a fixed effect design to test our predictions on the effect of mandatory IFRS adoption on financial analysts' coverage.

\subsection{Data}

The initial research sample consists of all the firms listed in London Stock Exchange that have available data in DataStream, Worldscope, and IBES international databases for the period between $1^{\text {th }}$ January 1990 and $31^{\text {st }}$ December 2013 (Note 2). The sample period was chosen to cover the periods before the adoption and after the adoption, thus the effect of IFRS adoption on the analysts' coverage can be examined. We took long time for two reasons. First, choosing a long period before and after IFRS adoption could result in a better measure of the effect of IFRS adoption on analysts' coverage. Since taking a long period before the adoption provides a better measure of the analysts' coverage levels before the mandatory adoption of IFRS. Second, Wang and Yu (2015) suggest that one of the advantages of taking a large sample for a longer time period is that the results and conclusions, drawn from this sample, are more representative. The investigation is undertaken in one country, the UK, to hold constant certain institutional factors such as stock listing requirements, accounting disclosure requirements, market microstructures and regulatory environments that may confound the results, thereby strengthening the reliability of our findings, as suggested by Ruland et al. (2007), and Paananen and Lin (2009). In addition, according to Schipper (2005) choosing one country instead of multi countries helps in minimizing the heterogeneity and the cross-countries differences that may have an effect on the dependent variable.

Only firms listed in the L.S.E, active and dead, with available data for the period from 1990 to 2013 were included in the sample. Following the prior research (Kim and Shi, 2012a, Hutton et al., 2009) the firms in financial, banking, and insurance industries, with SIC code 6000-6999 were excluded from the sample, because these industries have special regulations and financial accounting standards and the inclusion of these industries in the sample may distort the research results. Any firms with unavailable data to calculate the explanatory variables, and the dependent variablewere excluded from the sample also. After applying the previous procedures, the final sample consists of 10953 firm year observations collected from 1467 distinct UK listed firms for the period between 1990 and 2013.

\subsection{Methodology and Variables Measurement.}

\subsubsection{Methodology}

We estimate fixed effect regression model and perform robustness analyses to test the hypothesis as follows:

To test $\mathrm{H} 1$ we specifying the following regression model:

$$
F_{O l l}{ }_{i, t}=\alpha_{0}+\beta_{1} I F R S_{i, t}+\beta_{2} L E V_{i, t}+\beta_{3} M \backslash B_{i, t}+\beta_{4} S I Z E_{i, t}+\beta_{5} R O A_{i, t}+\text { Industry fixed effect }+\varepsilon_{i, t}
$$

In our robustness test we used different regression models to examine the effect of IFRS adoption on earnings quality.

\subsubsection{Variable Measurement}

\subsubsection{IFRS}

The information about the accounting standards followed in preparing the firm's financial statements was obtained 
from DataStream database. The DataStream code (WC07536) provides information about the accounting standards followed in preparing the financial statements for a specific firm. Table 4.2 provides a detailed description of the Worldscope code (WC07536) classification of the accounting standards followed by each firm. DataStream identifies 23 different accounting standards that are used by firms to prepare the financial statements. This identification ranges from local accounting standards $(07536=1)$, International Accounting Standards (IAS) pronounced by International Accounting Standards Committee IASC $(07536=2)$, U.S. standards $(07536=3)$, accounting standards that adopt local standards with other gridlines $(07536=08,10,17)$, or other hybrid type accounting standards that adopt local standards along with international accounting standards $(07536=18,19)$ (Note 3).This thesis follows J.-B. Kim and Shi (2012a), by identifying the firm as an IFRS adopter, if it adopts a full set of IFRS or IAS $(07536=02$ or 23$)$, and marked as a non-adopter if it adopts any other accounting standards. In particular, if the firm adopts IAS or IFRS with another set of accounting standards, then this firm is considered as a non-adopter.

Table 4.2. Worldscope description of Accounting followed (Field 07536) Worldscope fields 07536

\begin{tabular}{ll}
\hline & Worldscope description \\
\hline 1 & Local standards \\
2 & International standards \\
3 & U.S. standards (GAAP) \\
4 & Commonwealth countries standards \\
5 & EU standards \\
6 & International standards and some EU guidelines \\
7 & Specific standards set by the group \\
8 & Local standards with EU and IASC guidelines \\
9 & Not disclosed \\
10 & Local standards with some EU guidelines \\
11 & Local standards - inconsistency problems \\
12 & International standards - inconsistency problems \\
13 & US standards - inconsistency problems \\
14 & Commonwealth standards - inconsistency problems \\
15 & EEC standards - inconsistency problems \\
16 & International standards and some EU guidelines - inconsistency problems \\
17 & Local standards with some OECD guidelines \\
18 & Local standards with some IASC guidelines \\
19 & Local standards with OECD and IASC guidelines \\
20 & US GAAP reclassified from local standards \\
21 & Local standards with a certain reclassification for foreign companies \\
22 & Other \\
23 & IFRS \\
\hline
\end{tabular}

\subsubsection{Analysts' Coverage}

Consistent with the previous research (Piotroski and Roulstone (2004)Chan and Hameed (2006), (Lobo et al., 2012). The intensity of financial analysts' activity will be measured using the number of analysts who issued oneyear earnings per share forecast for a firm, during a given calendar year. The data for the number of analysts who issue earning per share forecast are to be obtained from $\mathrm{I} / \mathrm{B} / \mathrm{E} / \mathrm{S}$ international, which can be accessed through the DataStream, using the code number (EPS1NE) in the database.

\subsubsection{Firm Size}

Firm size, whether measured by firm's total asset (Paananen and Lin, 2009), or firm's total market value of equity (Oswald and Zarowin, 2007, Kim and Shi, 2012, Boubaker et al., 2014, Chan and Hameed, 2006, Devalle et al., 2010, Barth et al., 2008, Brochet et al., 2013, Lee and Liu, 2011) has been proved by prior literature to has a positive relation with stock price synchronicity.

Lobo et al. (2012) expect positive relation between analysts following and firm size. In addition, Baik et al. (2010) observe that firm size and the number of analysts following can be simultaneously determined because analyst coverage can lead to higher valuations and analysts are more likely to follow firms with higher values.Piotroski 
and Roulstone (2004)argue that including firm size on the regression model helps in controlling for omitted firmspecific factors. Where they mention that firm size is positively associated with various aspects of the firm's information environment, including media coverage and overall levels of investor interest. Differences in firms' information environments could influence financial analyst's decision to follow the firms. In addition, Bhushan(1989) argues that the firm size will affect the analysts' activity, where the large firms tend to attract more financial analysts.

\subsubsection{Growth Opportunity}

Growth firms may be more difficult to value because most of the value lies in the firm's growth opportunities rather than in the assets already in place (Bhushan, 1989, Barth et al., 2001). For this reason,Jiraporn et al. (2014) expect negative relation between growth opportunity and the number of financial analysts who follow the firms. However, Lobo et al. (2012) argue that Firms with higher growth are more likely to be followed by investors and generate higher trading commission. We thus control for growth by including the ratio of market value of equity to book value of equity.Following the outcomes of An and Zhang (2013), Bae et al. (2013), Hasan et al. (2014), He et al. (2013), Gul et al. (2010), and Hutton et al. (2009) the ratio of market value of equity to book value of equity will be used as one of the regression model control variables. The data for market to book value will be obtained from the DataStream database.

\subsubsection{Financial Leverage}

Beuselinck et al. (2010)suggest that the firms with high financial leverage have higher intrinsic risk factors which may enforce the investors to collect firm-specific information.(Jiraporn et al., 2014) document a significant negative relation between financial leverage and analysts' coverage.Following on from the prior literature, the firm's financial leverage ratio as measured by the firm's total debts to total assets ratio will be included in the regression model to control for the effect of firm's financial leverage on financial analysts' decision to follow the firms. The data needed to measure the firms' financial leverage will be obtained from the DataStream database.

\subsubsection{Firm Performance (ROA)}

Firm's profitability, is believed to have a relationship with the financial analyst's decision to follow the firm. We examine the impact of firm profitability on analyst coverage since prior studies suggest that analysts will be reluctant to follow non-profitable companies (Baik et al., 2010, Boubaker and Labégorre, 2008, Jiraporn et al., 2014).Hassan and Skinner(2016)finding suggests a significant positive effect of ROE on analysts' coverage. Following Masa'deh, Tayeh, Al-Jarrah, \&Tarhini (2015) and Obeidat, El-Rimawi, Maqableh, \& Al-Jarrah (2013) return on assets (ROA) will be used to measure firm's profitability.

\section{Discussion of Results}

\subsection{Descriptive Statistics and Preliminary Tests}

\subsubsection{Descriptive Statistics}

Table (2) presents descriptive statistics for the variables used in our analysis. On average the sample firms are followed by 6 financial analysts. At least there is one financial analysts issued expectation for next year earnings per share for the firms in our sample, and the highest number of financial analysts who provide one year expectation of EPS is 40. The statistics for other variables is as follow; growth opportunity (as measured by market value of equity to book value of equity) range from about -8 to 23.38 with a mean value 2.8 . Leverage (total debt to total assets), size (natural log for total assets), and ROA (net income to total assets) record a mean value of, $0.211,11.88$, and 2.92 , respectively.

Table 2 present the descriptive statistics for the variable of interest. The statistics are computed from 10953 firm year in the sample period 1990-2013

\begin{tabular}{cccccc}
\hline Variable name & Num. of Obs & MEAN & STD.DEV. & MIN & MAX \\
\hline GROWTH_OPPURTUNITY & 10953 & 2.876 & 4.082 & -8.07 & 23.38 \\
LEVERAGE & 10953 & 0.211 & 0.156 & 0.001 & 0.908 \\
SIZE & 10953 & 11.88 & 2.18 & 5.40 & 18.96 \\
ROA & 10953 & 2.924 & 14.249 & -38.47 & 29.28 \\
Analysts & 10953 & 5.816 & 6.274 & 1 & 40 \\
IFRS & 10953 & 0.516 & 0.499 & 0 & 1 \\
\hline
\end{tabular}




\subsubsection{Correlation Matrix}

Table 3 reports the correlation coefficient between key variables; the correlations are computed from 10953 firm year observations from 1467 UK listed firms for the period between 1990 and 2013.

\begin{tabular}{|c|c|c|c|c|c|c|}
\hline & GROWTH_OPPORTUNITY & LEVERAGE & IFRS & SIZE & Analysts & ROA \\
\hline GROWTH_OPPORTUNITY & 1 & & & & & \\
\hline LEVERAGE & -0.064 & 1 & & & & \\
\hline IFRS & -0.070 & 0.053 & 1 & & & \\
\hline SIZE & -0.055 & 0.149 & 0.050 & 1 & & \\
\hline Analysts & 0.057 & 0.120 & 0.001 & 0.800 & 1 & \\
\hline ROA & 0.003 & -0.044 & -0.067 & 0.329 & 0.300 & 1 \\
\hline
\end{tabular}

Table (3) Presents Pearson correlation matrix for the dependent (analysts coverage), independent (IFRS adoption) and all the control variables used in the regression analysis. The Pearson correlation coefficient is a measure of the strength of the linear relationship between two variables. The highest correlation coefficient is between firm size and analyst coverage. This significant positive correlation between firm size and analysts' coverage suggest that financial analysts tend to follow large firms. This result is consistent with the results of (Lobo et al., 2012, Baik et al., 2010).The lowest correction is between analysts' coverage and IFRS. The correlation between IFRS adoption and analysts' coverage is positive suggesting that the IFRS adoption could attract financial analysts to follow the firmsleads to higher earnings quality. Because the correlation coefficients for all the variables in the correlation analysis matrix are below $80 \%$, we can suggest that there is no multicollinearity problem in the data (Gujarati and Porter (2009).

\subsubsection{T-test Results}

Table 7 present the results of unpaired sample t_test of differences in means for our sample firms before IFRS adoption and after IFRS adoption. ANALYSTS_preIFRS is the mean of Financial analysts before IFRS adoption, ANALYSTS_post is the mean of Financial analysts after IFRS adoption. The test is computed from 10953 firm year observations from 1467 UK listed firms for the period between 1990 and 2013

\begin{tabular}{|c|c|c|c|c|c|}
\hline \multicolumn{6}{|l|}{ Unpaired t-test } \\
\hline Variable & observations & Mean & Std & $95 \%$ Conf. & interva \\
\hline ANALYSTS_Pre_IFRS adoption, IFRS $=0$ & 5302 & 5.63 & 0.0802 & 5.473 & 5.787 \\
\hline ANALYSTS_Post_IFRS adoption, IFRS $=1$ & 5651 & 5.991 & 0.0885 & 5.817 & 6.164 \\
\hline Combined & 10953 & 5.816 & 0.06 & 5.699 & 5.933 \\
\hline Diff & & -0.361 & 0.112 & -0.596 & -0.126 \\
\hline \multicolumn{6}{|c|}{ Diff $=$ Mean(ANALYSTS_Pre_IFRS) - Mean(ANALYSTS_Post_IFRS) } \\
\hline \multicolumn{6}{|l|}{$\mathrm{t}=-3.008$} \\
\hline \multicolumn{6}{|l|}{ p_value $=0.001 * * *$} \\
\hline
\end{tabular}

The result of t-test and test suggests that the mean value of analysts' coverage for post-IFRS adoption sample is significantly higher than that for pre-IFRS adoption sample. This result provides an initial indication that the mandatory IFRS adoption increases the number of financial analysts who cover the firms with their one year expectation of EPS.

\subsection{Main Results}

The main aim of this research is to examine the effect of IFRS adoption on the financial analysts' decision to cover the firms. to test this effect, we use regression model, which its results are documented in table 5. Thus, our variable of interest is the coefficient of the IFRS variable, which captures the incremental change in the number of financial analysts who follow the firms, for UK firms after mandatory IFRS adoption relative to pre-adoption period. The 
coefficient of this variable is significantly positive suggesting that the improved transparency and higher comparability of the financial reporting after the mandatory adoption of IFRS encourage financial analysts to follow the firms. this results is consistent with the findings of Kim and Shi (2012), where they find that the financial analysts follow the firms that voluntary adopt IFRS more than non-adopters.

The results also suggest that, the bigger firms are followed by more financial analysts, this result is consistent with the results of (Lobo et al., 2012, Baik et al., 2010). Consistent with the results of (Hassan and Skinner, 2016, Jiraporn et al., 2014) more financial analysts tent to cover more profitable firms. These firms with high growth opportunity also have a significant positive impact on analyst coverage. This results contradict with the suggestion of Jiraporn et al. (2014), who expect negative relation between growth opportunity and the number of financial analysts who follow the firms. while it corroborate the findings of Lobo et al. (2012), who argue that Firms with higher growth are more likely to be followed by investors and generate higher trading commission. Firm's financial leverage tends to have negative relation with analyst coverage variable.

Table 4. Multivariate regression analysis of IFRS adoption and analysts following. The sample consists of 10953 firm year observations from 1467 UK listed firms for the period between 1990 and 2013. This regression results based on panel data industry fixed effect model. The dependent variable is analysts following calculated by the number of financial analysts who follow the firm. The main independent variable is the mandatory adoption of IFRS; the first column presents the dependent variables. The second column presents the estimated coefficients change in the dependent variable as a result of one unit change in the independent variable. The third, fourth and fifth columns represent the standard errors, $t$ test and $\mathrm{p}_{-}$value results respectively. Here ${ }^{*}, * *, * * *$ present 10,5 , $1 \%$ levels of significant respectively for two tailed test.

\begin{tabular}{lllll}
\hline & coef. & robust std.err & $\mathrm{T}$ & $\mathrm{p}$ \\
\hline IFRS & 0.049 & 0.023 & 2.12 & $0.034^{* * *}$ \\
LEVERAGE & -0.116 & 0.081 & -1.43 & 0.152 \\
& & & 15.2 & \\
SIZE & 0.311 & 0.02 & 6 & $0.000^{* * *}$ \\
ROA & 0.001 & 0.000 & 2.17 & $0.030^{* * *}$ \\
GROWTH_OPPORTUNITY & 0.004 & 0.002 & 2.56 & $0.011^{* * *}$ \\
Const & -1.513 & 0.235 & -6.43 & $0.000^{* * *}$ \\
\hline
\end{tabular}

\section{Conclusions}

This study examines the impact of the mandatory adoption of IFRS on the analysts' coverage of the UK firms. Using a sample of 10,953 firm year observations from 1,467 distinct UK listed firms for the period between 1990 and 2013, we run regression analyses to examine the effect of mandatory IFRS adoption in the financial analysts following. The regression results suggest that analyst coverage, as measured by the number of financial analysts who provide next year expectation for firms EPS, did increased following the mandatory adoption of IFRS. This research documents clear and novel evidence on whether the mandatory adoption of IFRS improved information environment of the UK firms. The findings of this study may provide implications to the users of accounting information and the standard setters. The IFRS adoption has improved the number of financial analyst who cover the firms with their expectations of EPS, so it could benefit accounting information users in this respect. The findings may also help the standard setters in the UK in considering whether to adopt IFRS for UK's private firms in the future or not. Hence, the results can serve as a piece of timely evidence for evaluating the IFRS adoption in the UK.

In addition, this paper contributes to the literature that examines the economic consequences of mandatory IFRS adoption. Most of the literature on the consequences of mandatory IFRS adoption provide transitory evidence with low statistical power because of short history of IFRS adoption Brüggemann et al. (2012). Also, most of these papers provide evidence based on multi-countries data which make it difficult to distinguish the effect of IFRS from other concurrent changes that may affect the financial reporting content. By using large sample for long time period, from one county, we followed the future research recommendations of Brüggemann et al. (2012).

\section{References}

Aksu, M. H., \& Espahbodi, H. (2012). Impact of IFRS adoption and corporate governance principles on 
transparency and disclosure: the case of Istanbul stock exchange. Emerging Markets Finance and Trade.

AN, H., \& ZHANG, T. (2013). Stock price synchronicity, crash risk, and institutional investors. Journal of Corporate Finance, 21, 1-15.

BAE, K.-H., KIM, J.-M., \& NI, Y. (2013). Is Firm-specific Return Variation a Measure of Information Efficiency? International Review of Finance, 13, 407-445.

BAIK, B., KANG, J. K. \& MORTON, R. (2010). Why are analysts less likely to follow firms with high managerial ownership? Journal of Accounting, Auditing \& Finance, 25, 171-200.

BALL, R. (2006). International Financial Reporting Standards (IFRS): pros and cons for investors. Accounting and business research, 36, 5-27.

BARTH, M. E., KASZNIK, R., \& MCNICHOLS, M. F. (2001). Analyst coverage and intangible assets. Journal of accounting research, 39, 1-34.

BARTH, M. E., LANDSMAN, W. R., \& LANG, M. H. (2008). International Accounting Standards and Accounting Quality. Journal of Accounting Research, 46, 467-498.

BEUSELINCK, C., JOOS, P., KHURANA, I. K., \& VAN DER MEULEN, S. (2010). Mandatory IFRS reporting and stock price informativeness. Tilburg University.

BHUSHAN, R. (1989). Firm characteristics and analyst following. Journal of Accounting and Economics, 11, 255-274.

BOUBAKER, S., \& LABÉGORRE, F. (2008). Ownership structure, corporate governance and analyst following: A study of French listed firms. Journal of Banking \& Finance, 32, 961-976.

BOUBAKER, S., MANSALI, H., \& RJIBA, H. 2014. Large controlling shareholders and stock price synchronicity. Journal of Banking \& Finance, 40, 80-96.

BROCHET, F., JAGOLINZER, A. D., \& RIEDL, E. J. (2013). Mandatory IFRS Adoption and Financial Statement Comparability. Contemporary Accounting Research/Recherche Comptable Contemporaine, 30, 1373-1400.

BRÜGGEMANN, U., HITZ, J.-M., \& SELLHORN, T. (2012). Intended and Unintended Consequences of Mandatory IFRS Adoption: A Review of Extant Evidence and Suggestions for Future Research. European Accounting Review, 22, 1-37.

BYARD, D., LI, Y., \& YU, Y. (2011). The Effect of Mandatory IFRS Adoption on Financial Analysts' Information Environment. Journal of Accounting Research, 49, 69-96.

CHAN, K., \& HAMEED, A. (2006). Stock price synchronicity and analyst coverage in emerging markets. Journal of Financial Economics, 80, 115-147.

DASKE, H., HAIL, L., LEUZ, C., \& VERDI, R. (2008). Mandatory IFRS Reporting around the World: Early Evidence on the Economic Consequences. Journal of Accounting Research, 46, 1085-1142.

DEFOND, M. L., HUNG, M., LI, S., \& LI, Y. (2015). Does Mandatory IFRS Adoption Affect Crash Risk? The Accounting Review, 90, 265-299.

DEVALLE, A., ONALI, E., \& MAGARINI, R. (2010). Assessing the Value Relevance of Accounting Data After the Introduction of IFRS in Europe. Journal of International Financial Management \& Accounting, 21, 85119.

ERNST, Y. (2006). IFRS: Observations on the implementation of IFRS. Ernst \& Young Publications.

GUJARATI, D. N., \& PORTER, D. (2009). Basic Econometrics Mc Graw-Hill International Edition.

GUL, F. A., KIM, J.-B., \& QIU, A. A. (2010). Ownership concentration, foreign shareholding, audit quality, and stock price synchronicity: Evidence from China. Journal of Financial Economics, 95, 425-442.

HASAN, I., SONG, L., \& WACHTEL, P. (2014). Institutional development and stock price synchronicity: Evidence from China. Journal of Comparative Economics, 42, 92-108.

HASSAN, O. A. G., \& SKINNER, F. S. (2016). Analyst coverage: Does the listing location really matter? International Review of Financial Analysis, 46, 227-236.

HE, W., LI, D., SHEN, J., \& ZHANG, B. (2013). Large foreign ownership and stock price informativeness around the world. Journal of International Money and Finance, 36, 211-230. 
HEALY, P. M., \& PALEPU, K. G. (2001). Information asymmetry, corporate disclosure, and the capital markets: A review of the empirical disclosure literature. Journal of Accounting and Economics, 31, 405-440.

HORTON, J., SERAFEIM, G., \& SERAFEIM, I. (2013). Does Mandatory IFRS Adoption Improve the Information Environment?*. Contemporary Accounting Research, 30, 388-423.

HOUQE, M. N., EASTON, S., \& VAN ZIJL, T. (2014). Does mandatory IFRS adoption improve information quality in low investor protection countries? Journal of International Accounting, Auditing and Taxation, 23, 87-97.

HUTTON, A. P., MARCUS, A. J., \& TEHRANIAN, H. (2009). Opaque financial reports, R2, and crash risk. Journal of Financial Economics, 94, 67-86.

JIRAPORN, P., LIU, Y., \& KIM, Y. S. (2014). How do powerful CEOs affect analyst coverage? European Financial Management, 20, 652-676.

KIM, J.-B., \& SHI, H. (2012). Voluntary IFRS Adoption, Analyst Coverage, and Information Quality: International Evidence. Journal of International Accounting Research, 11, 45-76.

KIM, J.-B., \& SHI, H. (2012). IFRS Reporting, Firm-Specific Information Flows, and Institutional Environments: International Evidence. Review of Accounting Studies, 17, 474-517.

KIM, J.-B., SHI, H., \& ZHOU, J. (2014). International Financial Reporting Standards, Institutional Infrastructures, and Implied Cost of Equity Capital around the World. Review of Quantitative Finance and Accounting, 42, 469-507.

LAMBERT, R. A., LEUZ, C., \& VERRECCHIA, R. E. (2012). Information Asymmetry, Information Precision, and the Cost of Capital. Review of Finance, 16, 1-29.

LEE, D. W., \& LIU, M. H. (2011). Does more information in stock price lead to greater or smaller idiosyncratic return volatility? Journal of Banking \& Finance, 35, 1563-1580.

LI, S. (2010). Does Mandatory Adoption of International Financial Reporting Standards in the European Union Reduce the Cost of Equity Capital? The Accounting Review, 85, 607-636.

LOBO, G. J., SONG, M., \& STANFORD, M. (2012). Accruals quality and analyst coverage. Journal of Banking \& Finance, 36, 497-508.

Masa'deh, R., Tayeh, M., Al-Jarrah, I., \& Tarhini, A. (2015). Accounting vs. market-based measures of firm performance related to information technology investments. International Review of Social Sciences and Humanities, 9(1), 129-145.

Obeidat, B., El-Rimawi, S., Maqableh, M., \& Al-Jarrah, I. (2013). Evaluating the profitability of the Islamic banks in Jordan. European Journal of Economics, Finance and Administrative Sciences, 56, 27-36.

OSWALD, D. R., \& ZAROWIN, P. (2007). Capitalization of R\&D and the Informativeness of Stock Prices. European Accounting Review, 16, 703-726.

PAANANEN, M., \& LIN, H. (2009). The Development of Accounting Quality of IAS and IFRS over Time: The Case of Germany. Journal of International Accounting Research, 8, 31-55.

PIOTROSKI, J. D., \& ROULSTONE, D. T. (2004). The Influence of Analysts, Institutional Investors, and Insiders on the Incorporation of Market, Industry, and Firm-Specific Information into Stock Prices. The accounting review, 79, 1119-1151.

RULAND, W., SHON, J., \& ZHOU, P. (2007). Effective controls for research in international accounting. Journal of Accounting and Public Policy, 26, 96-116.

SCHIPPER, K. (2005). The introduction of International Accounting Standards in Europe: Implications for international convergence. European Accounting Review, 14, 101-126.

VELDKAMP, L. L. (2006a). Information Markets and the Comovement of Asset Prices. Review of Economic Studies, 73, 823-845.

WANG, J. W., \& YU, W. W. (2015). The Information Content of Stock Prices, Legal Environments, and Accounting Standards: International Evidence. European Accounting Review, 24, 471-493. 


\section{Notes}

Note 1. See Regulation (EC) 1606/2002 for further information

Note 2. The three databases are combined in one software called DataStream published by Thomson Reuter.

Note 3. The information about Worldscope accounting standards classifications is retrieved from Thomson Reuters (2012) website.

\section{Copyrights}

Copyright for this article is retained by the author(s), with first publication rights granted to the journal.

This is an open-access article distributed under the terms and conditions of the Creative Commons Attribution license (http://creativecommons.org/licenses/by/4.0/). 